\title{
84. Chromosomal Studies on Interspecific Hybrids of Butterflies (Papilionidae, Lepidoptera). V
}

\author{
Studies in crosses among P. polytes, P. fuscus, \\ P. macilentus, and P. memnon \\ By Kodo MAEKI*) and Shigeru A. AE**) \\ (Communicated by Sajiro Makino, M. J. A., June 8, 1976)
}

Inquiring into the systematic relationship among the species of Papilionidae through hybridization experiments, we have been dealing with the analysis of the meiotic chromosomes in interspecific hybrids of Papilio, with particular concern to the male meiotic mechanism in many crosses in relation to the view of genic homology.

The crosses hitherto available are: Papilio polyctor $\times P$. bianor, $P$. polyctor $\times P$. maackii (Maeki and Ae 1966), P. polytes $\times P$. helenus, $P$. polytes $\times P$. protenor, $P$. polytes $\times P$. macilentus (Maeki and Ae 1970), $P$. bianor $\times P$. paris, $P$. paris $\times P$. maackii, $P$. bianor $\times P$. maackii, $P$. polytes $\times P$. maackii (Maeki and Ae 1975), P. nepheles $\times P$. polytes, $P$. nepheles $\times P$. helenus, $P$. polytes $\times P$. aegeus, and $P$. aegeus $\times P$. helenus (Maeki and Ae 1976a), with particular interest in pairing of chromosomes at the first meiosis in males. The hybrids from the following crosses were subjected to the present study: $P$. polytes $\times P$. fuscus, $P$. fuscus $\times P$. macilentus, and $P$. macilentus $\times P$. memnon. The hybrids produced artificially by $\mathrm{Ae}$ (1966, 1973, Nanzan University) have provided materials for chromosomal studies by Maeki (Kwansei Gakuin University). The usual paraffin-method has been adopted in this investigation.

Results. Examples of the chromosomal configurations of interspecific Papilio-hybrids concerned here are shown in photomicrographs. Four parental species of Papilio; $P$. polytes, $P$. fuscus, $P$. macilentus and $P$. memnon, were found to possess 30 chromosomes in n. Apparently, their chromosomes showed no appreciable morphological difference between different species. In the following, chromosomal analyses were made in some detail in each hybrid group.

1. Papilio polytes 우 (from Japan) $\times$ Papilio fuscus $\hat{\circ}$ (from Australia). Counts of chromosomes in hybrids were made in 19 M-I

*) Biological Laboratory, Faculty of Science, Kwansei Gakuin University, Nishinomiya, Japan.

**) Biological Laboratory, Nanzan University, Yamazato-cho, Showa-ku, Nagoya, Japan. 


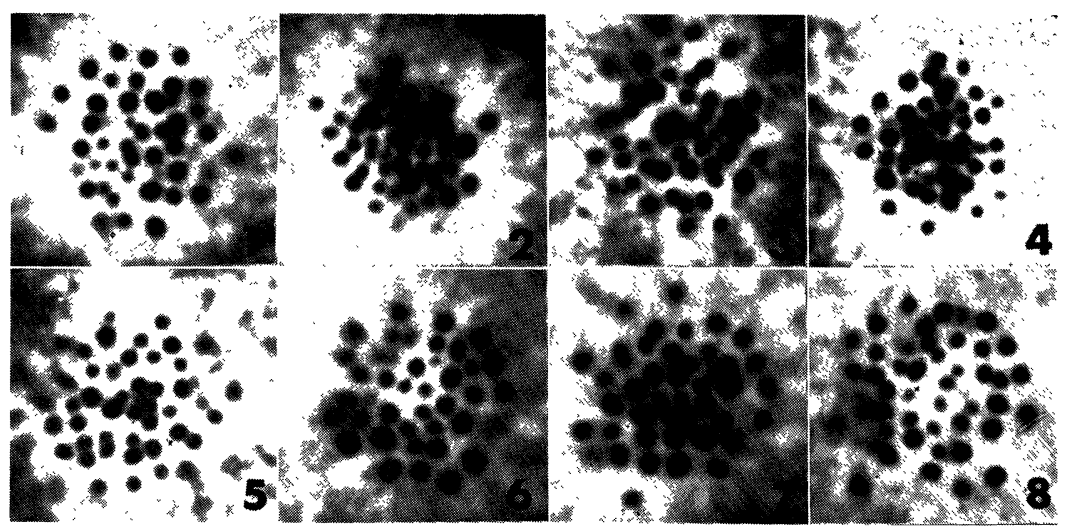

Figs. 1-8: Meiotic chromosomes of Papilio hybrids (M-I, $\times 3000$ ). 1-2: $P$. polytes $\times P$. fuscus, $\mathrm{F}_{1}$. 3-5: $P$. fuscus $\times P$. macilentus, $\mathrm{F}_{1}$. 6-8: $P$. macilentus $\times P$. memnon, $\mathrm{F}_{1}$, (1: $n, 46$. 2: $n, 48.3: n, 52.4: n, 47$. $5: n, 45.6: n, 40.7: n, 43.8: n, 48)$.

nuclei derived from six hybrids males (Nos. 3, 4, 5, 15, 43 and 44 from Brood 0-62-43). The chromosomes of these hybrids showed a considerable variation in the n-number, ranging from 46 to 57 (Figs. 1-2). The chromosome-number distribution as observed in $19 \mathrm{M}-\mathrm{I}$ cells was as below:

$$
\begin{aligned}
& n, 46 \ldots \ldots 1 \text { nucleus } \quad n, 52 \ldots \ldots 2 \text { nuclei } \\
& n, 47 \ldots \ldots 1 \quad n \quad n, 53 \ldots \ldots .1 \text { nucleus } \\
& n, 48 \ldots \ldots 1 " n, 54 \ldots \ldots .3 \text { nuclei } \\
& n, 49 \ldots \ldots 1 \quad n, 55 \ldots \ldots 2 \text { " } \\
& n, 50 \ldots \ldots 1 \quad n, 56 \ldots \ldots 2 \text { " } \quad \ldots \ldots \\
& n, 51 \ldots \ldots 3 \text { nuclei } \quad n, 57 \ldots \ldots 1 \text { nucleus. }
\end{aligned}
$$

A small number of dividing cells available for counting in the six males seems to suggest a considerable abnormality of the meiotic phases occurring in them. A nucleus having 46 chromosomes had 32 univalents, and a 57-chromosome-cell showed 54 univalents, indicating that there were a number of chromosomes which remained without pairing. The cells showing $\mathrm{n}, 51$ to $\mathrm{n}, 56$ occurred at a frequency of $68 \%$.

2. Papilio fuscus 우 (from Australia) $\times$ Papilio macilentus $\hat{\circ}$ (from Japan). Chromosome counts were available in $48 \mathrm{M}$-I cells from three hybrid males (Nos. 1,3 and 8 from Brood Fu-2). The M-I chromosome-numbers of the hybrids ranged in variation from 44 to 55 (Figs. 3-5). The chromosome complement consisting of 13 bivalents and 34 univalents was most frequent giving $20.8 \%$ of the observed cells. The chromosome-number distributions shown in 48 M-I cells studied were as follows: 


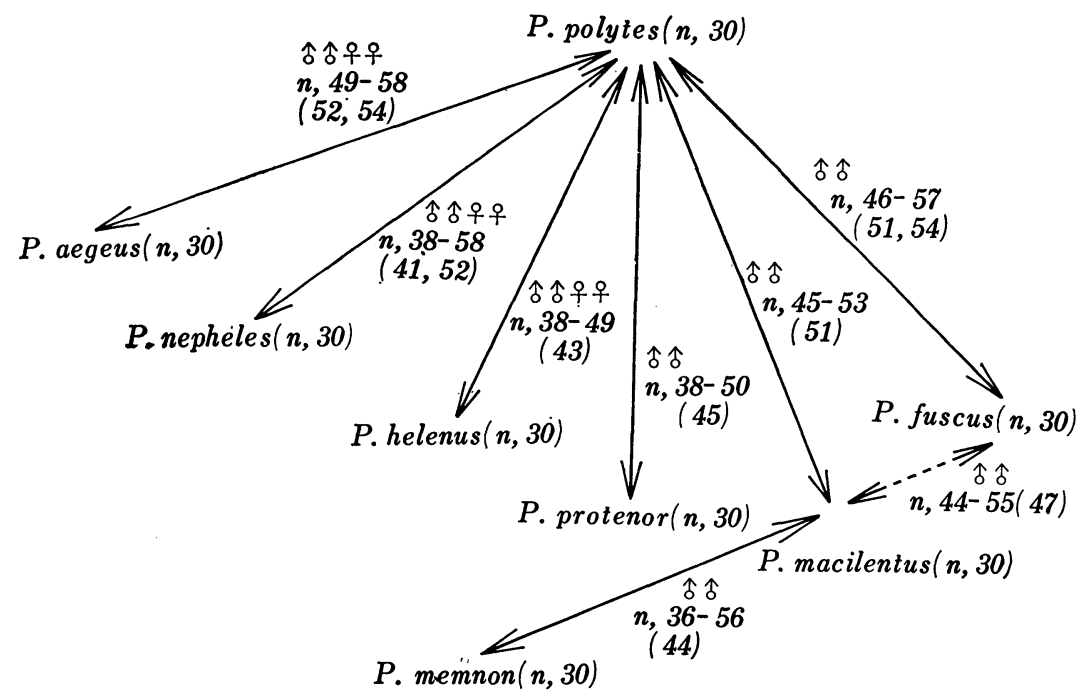

Fig. 9. Diagram showing the relationship of eight Papilio species, based on analysis of meiotic chromosomal pairing in hybrids specimens.

\begin{tabular}{|c|c|c|}
\hline$n, 44$ & $\ldots \ldots \ldots 4$ & nucle \\
\hline$n, 45$ & $\ldots \ldots \ldots 4$ & " \\
\hline$n, 46$ & $\ldots \ldots \ldots$ & " \\
\hline$n, 47$ & $\ldots \ldots \ldots 10$ & " \\
\hline$n, 48$ & $\ldots \ldots$ & " \\
\hline$n, 49$ & . 6 & 1 \\
\hline
\end{tabular}

$$
\begin{aligned}
& n, 50 \ldots \ldots .4 \text { nuclei } \\
& n, 51 \ldots \ldots 1 \text { nucleus } \\
& n, 52 \ldots \ldots 2 \text { nuclei } \\
& n, 53 \ldots \ldots 2 \\
& n, 54 \ldots \ldots .1 \text { nucleus } \\
& n, 55 \ldots \ldots .2 \text { nuclei }
\end{aligned}
$$

3. Papilio macilentus 우 (from Japan) $\times$ Papilio memnon $\hat{\circ}$ (from Japan). Eighty-seven M-I cells derived from seven hybrid males (Nos. 1, 2, 3, 4, 5, 8 and 9 from Brood C-69-2) were available for chromosome counts. It was shown that the chromosomes observed in these M-I cells varied in number from 36 to 56 (Figs. 6-8), and that the variation showing 42 to 46 chromosomes was frequent showing $55 \%$ of these cells under study, the modal number being 44 . In the modal cells with 44 chromosomes, the complement showed a chromosome constitution of 28 univalents and 16 bivalents. The chromosome-number distributions observed in $87 \mathrm{M}-\mathrm{I}$ cells were shown as below:

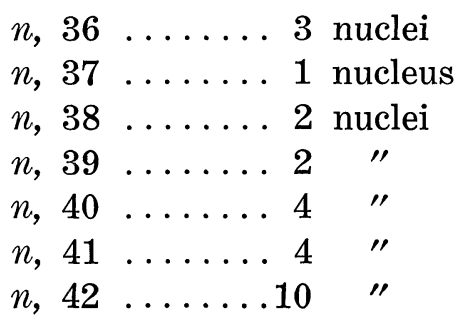

$n, 36 \ldots \ldots 3$ nuclei

$n, 37 \ldots \ldots \ldots 1$ nucleus

$n, 38 \ldots \ldots 2$ nuclei

$n, 39 \ldots \ldots 2$

$n, 41 \ldots \ldots .4 \quad$

$n, 42 \ldots \ldots .10$

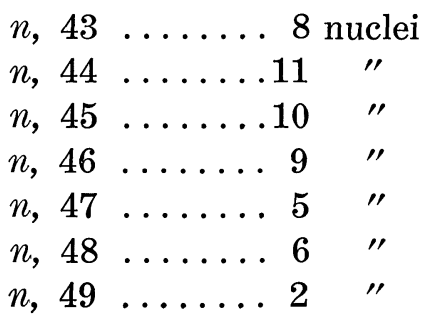




$$
\begin{array}{lllllll}
n, 50 & \ldots \ldots & 2 \text { nuclei } & n, 53 & \ldots \ldots & 3 \text { nuclei } \\
n, 51 & \ldots & 4 & 4
\end{array}
$$

Remarks. Ranges of the chromosome-number variations and of the modal numbers so far observed in the interspecific hybrids between $P$. polytes and several species belonging to the black Papilio group were obtained as follows:

$\begin{array}{lcc}\text { Cross } & \text { Number variation } & \text { Mode } \\ \times \text { helenus } & 38-49 & 43 \\ \times \text { macilentus } & 38-50 & 45 \\ \times \text { nepheles } & 45-53 & 51 \\ \times \text { fuscus } & 38-58 & 41,52 \\ \times \text { aegeus } & 46-57 & 51,54 \\ & 49-58 & 52,54\end{array}$

Referring to the above data, the following view may be naturally induced on the basis of genic homology that $P$. polytes is most closely related to $P$. helenus among those 6 species. Two species, $P$. fuscus and $P$. aegeus, which have a distribution in the Australian region, seem somewhat remotely related with $P$. polytes, whose major distribution covers the Oriental region.

A fact of noteworthy is that, viewed from genic homology, $P$. macilentus is closer to $P$. memnon belonging to the memnon subgroup than the other species of the black Papilio group.

Acknowledgements. We thank Emeritus Professor Dr. Sajiro Makino for expert revision of the manuscript with invaluable criticism, and Dr. Charles L. Remington for helpful encouragement.

\section{References}

Ae, S. A.: Spec. Bull. Lep. Soc. Jap., No. 2, 75 (1966) and No. 5, 89 (1971).

Lorkovic, Z.: Glasnik Hrv. Priridosl. Drustvo, Zagreb 2B, 2-3, 57 (1950).

_- Biol. Glasnik, 21, 95 (1968).

Maeki, K., and Ae, S. A.: Spec. Bull. Lep. Soc. Jap., No. 2, 121 (1966) and No. 4, 131 (1970).

_-_: Proc. Japan Acad., 51, 577 (1975).

_- Proc. Japan Acad., 52, 236 (1976).

Maeki, K., and Remington, C. L.: Journ. Lepid. Soc., 13, 193 (1960).

Makino, S.: A review of the chromosome numbers in animals. Rev. ed., $300 \mathrm{pp}$. Hokuryukan, Tokyo (1956).

Remington, C. L.: Proc. 10th Int. Congr. Ent., 2, 787 (1958).

White, M. J. D.: Animal Cytology and Evolution. Third ed., 961 pp. Univ. Press, Cambridge (1973). 